\title{
APPLICATION OF A RADIAL TURBINE 1-D MODEL
}

\section{ZDENĚK ŽÁK, OLDŘICH VÍTEK, JAN MACEK}

Czech Technical University, Vehicle Centre of Sustainable Mobility, Technická 4, 16607 Praha 6

E-mail: zdenek.zak@fs.cvut.cz, oldrich.vitek@fs.cvut.cz, jan.macek@fs.cvut.cz

\section{SHRNUTí}

Článek, na několika přikladech, popisuje simulace s využitím 1-D modelu radiální turbíny turbodmychadla. Cílem je popsat současný stav a ukázat potenciál 1-D přístupu v oblasti modelování turbodmychadla. Pro možnost testování modelů turbíny a kompresoru byly vyvinuty rozmanité simulační nástroje. Model turbínového testovacího stavu umožňuje provozovat turbínu v široké provozní oblasti. Model zkušebního stavu turbodmychadel se spalovací komorou je vhodný pro prǐřzení kompresoru turbíně. Článek uzavírají výsledky fungování modelu turbíny ve spojení s modelem virtuálního čtyřtaktního zážehového motoru. KLIČCVÁ SLOVA: I-D MODEL RADIÁLNII TURBÍNY, TURBODMYCHADLO, TURBÍNA, KOMPRESOR, TURBÍNOVÝ TESTOVACI STAV, ZKUŠEBNII STAV SE SPALOVACÍ KOMOROU, PŘIIŔAZENII KOMPRESORU A TURBÍNY, GT-POWER

\section{ABSTRACT}

The paper presents the simulation results of several applications of a radial turbine 1-D model. The aim is to describe the current situation and to demonstrate the potential of this approach for turbocharger modelling. Various simulation tools have been developed for testing turbine and compressor performance. The test bed allows the turbine to be operated across a broad working range. The model of the hot gas stand is suitable for turbine-compressor matching. The results of turbine behaviour in conjunction with the model of a virtual four-stroke SI engine are discussed.

KEYWORDS: RADIAL TURBINE I-D MODEL, TURBOCHARGER, TURBINE, COMPRESSOR, TURBINE TEST BED, HOT GAS STAND, TURBINE-COMPRESSOR MATCHING, GT-POWER

\section{INTRODUCTION}

The goal of the contribution is to compare the 1-D model results and experiments with interpolation/extrapolation using an in-house procedure and GT-Power interpolation. The most frequently used turbocharger turbine modelling method is the 0-D approach based on turbine speed (Figure 1) and efficiency (Figure 2) maps. These SAE maps are based on experimental data from the turbocharger manufacturer. Measured data usually cover only a narrow area and the level of accuracy is relatively low. The problem of this approach is that the user of simulation software is able to obtain many different turbine maps from the same experimental data (Figure 3); but which one is correct? It is necessary to leave the trial and error approach during the development process and change the method for modelling a turbocharger turbine.

The challenge faced is optimisation of turbine design for the unsteady operation mode in conjunction with the reciprocating internal combustion engine. Improvement potential exists particularly at the low end of the engine WOT (wide-open- throttle) curve, and in appropriate prediction of transient load response. The next important reason for the work is that we still lack a proper twin scroll (Figure 4) model. The contribution describes the applications and results from testing the current radial turbine 1-D unsteady physical model. The advantages of the 1-D approach are the feasibility of calibration based on experiments, direct connection with the 1-D model of an internal combustion engine and the possibility of comprehensive optimization. The simulation of transient states is also practicable. The 3-D simulations are very time consuming and the calibration process of a 3-D model is too complicated.

A central streamline 1-D turbine model has been developed. It uses the basic templates of a 1-D manifold solver. It consists of ducts featuring total pressure and/or temperature changes and losses (inlet volute, nozzle blades, rotating impeller channels and outlet casing with a diffuser). The model covers the aerodynamics of turbine flow and mechanical losses in bearings. The mechanical losses in bearings are calculated by the semi-empiric regression 


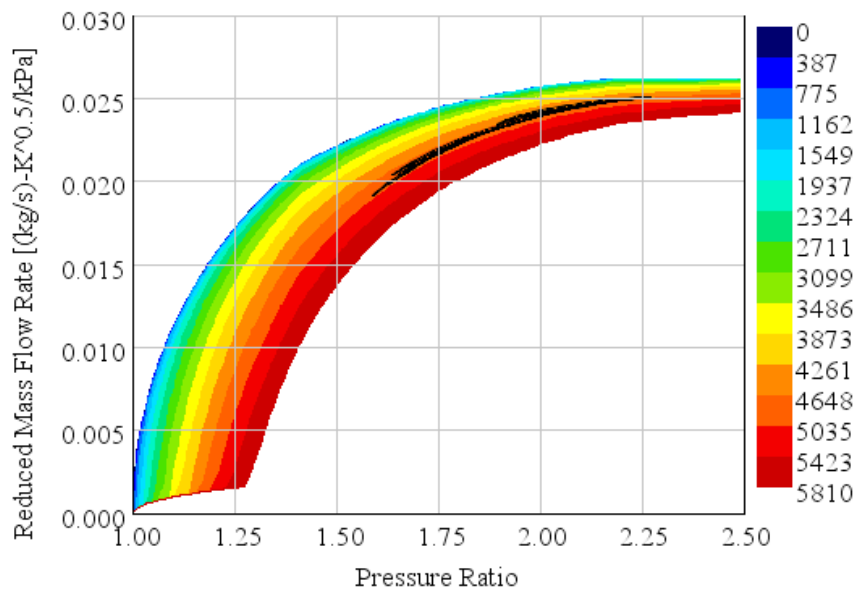

FIGURE 1: Turbine speed map with depicted working area over the engine cycle (black), speed lines (reduced speed RPM/K^0.5)

OBRÁZEK 1: Mapa turbíny s vyznačenou pracovní oblastí v průběhu cyklu motoru (černá), rychlostní cáry (redukované otáčky RPM/K^0.5)

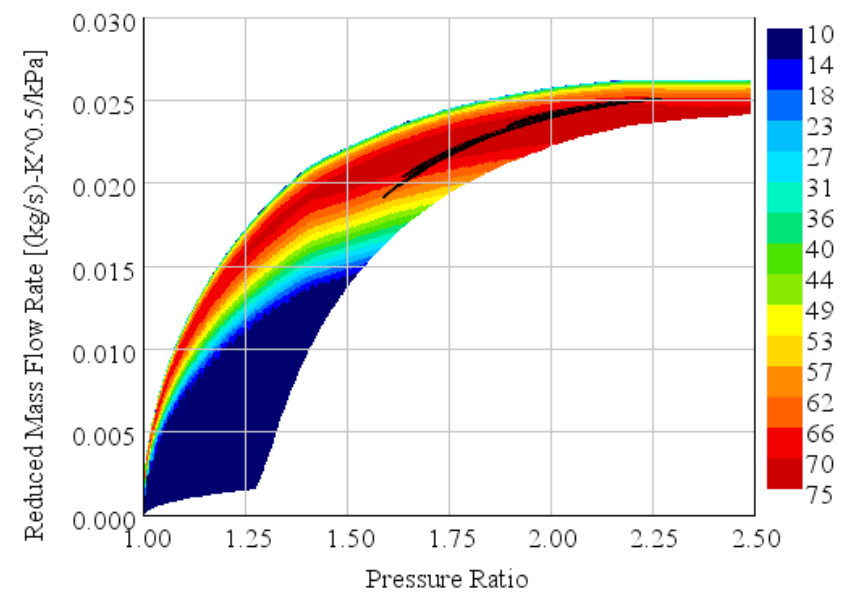

FIGURE 2: Turbine efficiency map with depicted working area over the engine cycle (black)

OBRÁZEK 2: Mapa turbíny s vyznačenou pracovní oblastí v průběhu cyklu motoru (černá)

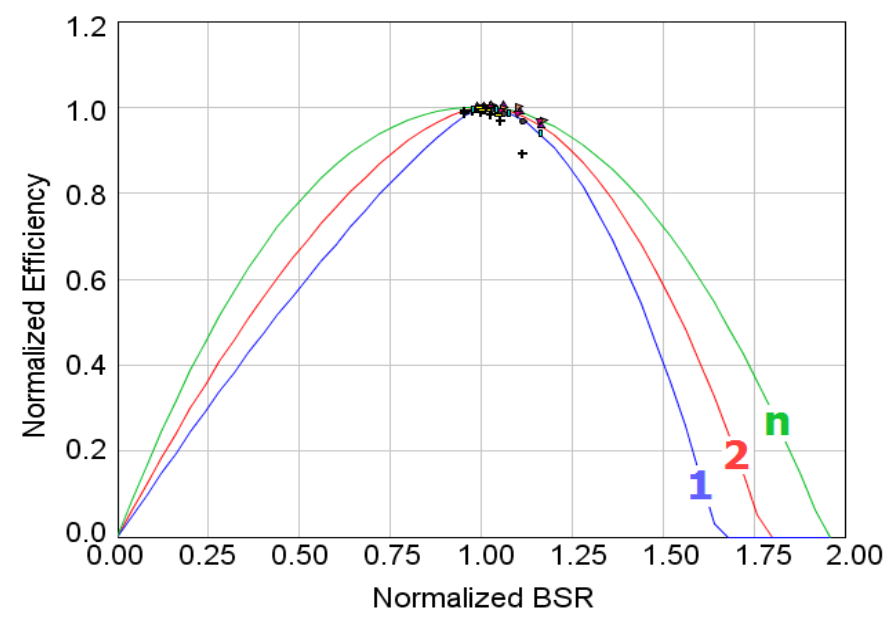

FIGURE 3: Turbine efficiency fit - plots from simulation software OBRÁZEK 3: Reprezentace účinnosti turbíny v simulačním programu model, which respects the load of radial and thrust bearings, oil viscosity and turbine size. The turbine power assessment is based on integration of local changes of angular momentum. The torque acting on the impeller is integrated using a Eulerian angular momentum balance. The turbine speed results from an angular momentum equation for the turbine-compressor shaft. The shaft is driven by a torque, which is calculated according to the results of torque integration at impeller pipe vertexes. The torque is reduced by the windage losses calculated from turbine speed, dimensions and gas density close to the impeller disc.

The leakages are modelled using flow split elements and orifices with corresponding discharge coefficients. The model capability depends on the quality of the calibration process. An adequate range of available experimental data is necessary. The carefully calibrated 1-D turbine model enables extrapolation outside the range of experiments. The model description is given in [8], [9], [10] and [11]. The potential of the model rests in physical simulation of twin scroll turbines (Figure 4), prediction of turbine behaviour at low speeds and evaluation of the influence of an outlet diffuser. To date two versions (CZ K36 and CZ C12 VGT) of the model have been developed and properly calibrated using experimental data.

The results of simulation using the 1-D code may contribute to the further development of a radial turbine. A description of various simulation tools for testing the turbocharger performance and simulation results follow.

\section{SIMULATION RESULTS}

\subsection{VIRTUAL TURBINE TEST BED}

The first step was to develop the turbine test bed model (Figure 5). The test bed is a simple but strong simulation tool. The advantage of this simple model is that it is easy to simulate any operation mode of the turbine. It is possible to unload or overload the turbine over a wide range. The specified inputs are inlet pressure, inlet temperature and required speed. The model outputs such as reduced speed [RPM/ $/ \wedge 0.5]$, reduced mass flow rate $\left[(\mathrm{kg} / \mathrm{s})^{*}\left(\mathrm{~K}^{\wedge} 0.5\right) / \mathrm{bar}\right]$, pressure ratio and isentropic efficiency are calculated using the sensed values. The virtual test bed has been used for turbine testing, comparing of results and generating all 0-D turbine maps. The fundamental problem of $0-D$ turbine map creation is representation of the entered data in a specific simulation code. The results of simulation are strongly linked to the quality of the turbine fitting.

All 0-D turbine maps for CZ K36 are based on the results of the 1-D turbine model (type CZ K36), which was tested on the virtual test bed over a broad range of blade speed ratios. Various 0-D turbine maps (SAE map with user fitting in GT-Power, Lookup table and Regression model based on experimental data) are presented in the following paragraphs. 


\section{SAE map with user fitting in GT-Power}

The goal of the 0-D map creation technique in SAE format was to find an accurate fit for turbine mass flow and efficiency that keeps errors as low as possible in comparison with the results of the 1-D model. Essential were the values of mass flow rate, efficiency, blade speed ratio, power and discharge coefficient. This technique utilizes the facilities of user fitting in GT-Power. It is clear that the resultant turbine fit is always something of a compromise, but the maximum error of the 0-D SAE map with user fitting compared to the 1-D data is less than $5 \%$ over a wide range. The resultant fit for turbine efficiency is plotted in Figure 6.

\section{Lookup table}

The other method is utilization of a lookup table in GT-Power, where the solver uses the data supplied by the user directly without any fitting. The code linearly interpolates between the given points and extrapolates the mass flow rate and efficiency of the lowest pressure ratio on the given speed line down to a pressure ratio equal to one. It will take the lowest pressure ratio on the speed line and only apply the same mass flow rate and efficiency at the pressure ratio equal to one. The lookup table is convenient only if a broad range of speeds and pressure ratios is available, but on the other hand the number of rows is strictly limited. Examples of results from the 1-D turbine model (deep blue) and 0-D using the lookup table (red) are shown in the pictures. The dependence of efficiency on blade speed ratio is shown in Figure 7. The pattern of reduced mass flow rate is shown in Figure 8 and the discharge coefficient in Figure 9. The level of accuracy of the obtained results (CZ K36 type) seems to be sufficient.

\section{Regression model based on experimental data}

The experimental data were fitted using the in-house regression procedure. The regression relationships were built into GT-Power with the aid of our own turbine user model. The solver utilizes the appropriate output data of the user model directly without any interpolation or extrapolation.

\subsection{VIRTUAL HOT GAS STAND - STEADY STATE}

The one-loop hot gas stand model (Figure 10) has been developed and properly tested. The model enables control of turbocharger speed, turbine pressure ratio or compressor pressure ratio by controlling the mass of fuel. It is also possible to simulate the transient states by controlling the fuel mass flow rate over time. The operating points of the CZ K36 1-D turbine, which has been loaded with a suitable

compressor with a reference wheel diameter, are displayed in Figure 11 along with the constant pressure ratio lines obtained using the virtual test bed. The prediction of turbine behaviour at

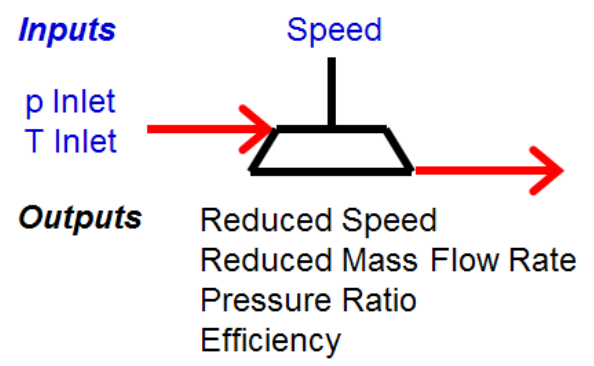

FIGURE 5: Schematic diagram of a virtual test bed OBRÁZEK 5: Schéma virtuálního testovacího stavu

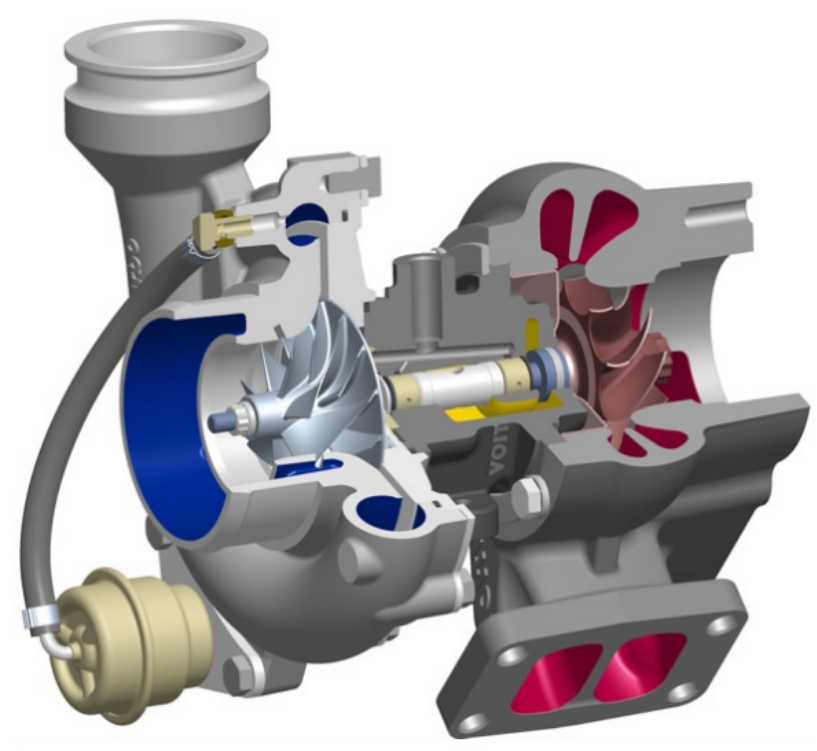

FIGURE 4: Layout of a twin scroll turbine [Voith Turbo Aufladungssysteme GmbH \& Co KG] OBRÁzEK 4: Provedení dvouvstupové turbíny [Voith Turbo Aufladungssysteme GmbH \& Co KG]

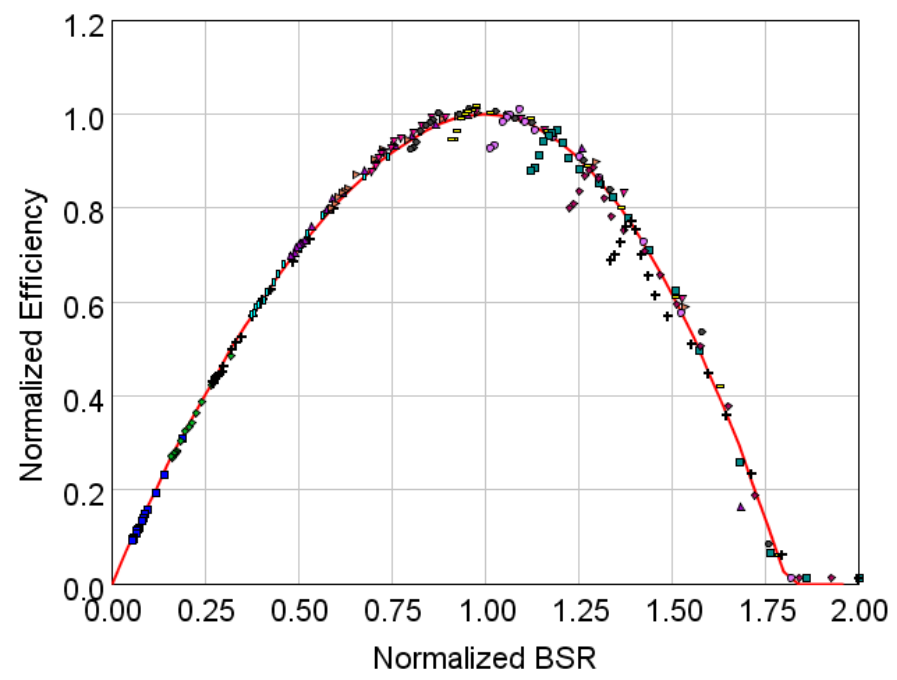

FIGURE 6: Turbine efficiency fit in GT-Power, SAE map with user fitting (CZ K36) OBRÁZEK 6: Reprezentace účinnosti turbíny v GT-Power, SAE mapa s uživatelsky definovanou reprezentací dat (CZ K36) 


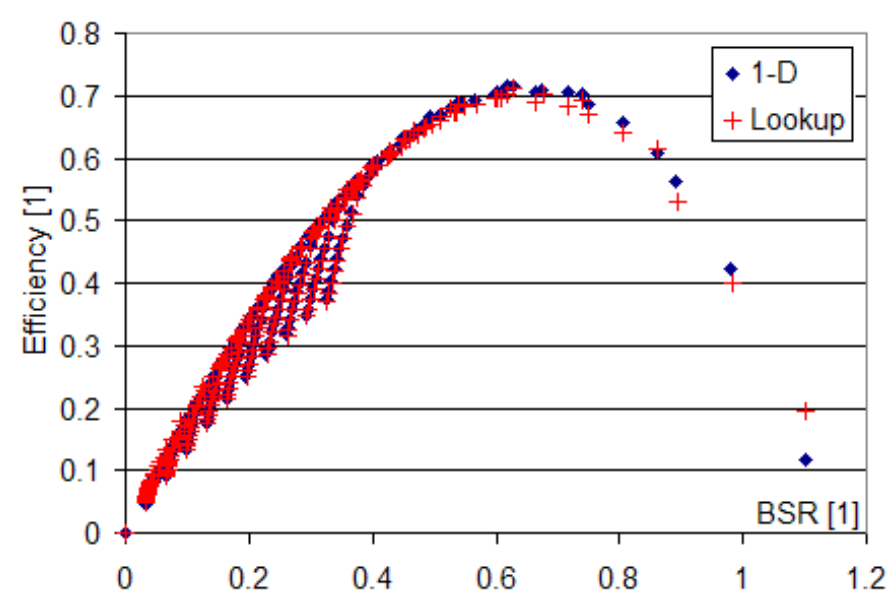

FIGURE 7: Dependence of efficiency on blade speed ratio, 1-D model (blue), Lookup table (red)

OBRÁZEK 7: Závislost účinnosti na rychlostním poměru, 1-D model (modrá), tabulka dat (červená)

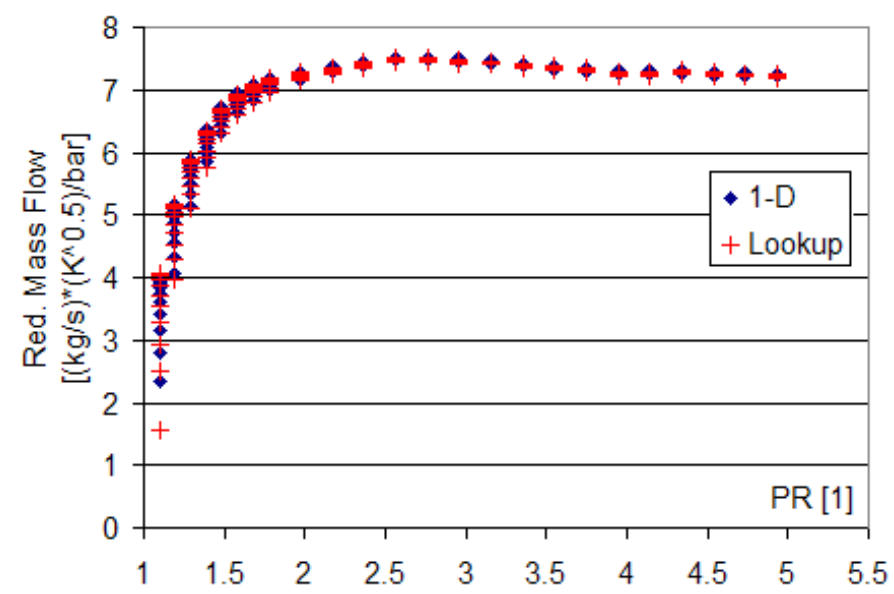

FIGURE 8: Dependence of reduced mass flow rate on pressure ratio, 1-D model (blue), Lookup table (red)

OBRÁZEK 8: Závislost redukovaného průtoku na tlakovém poměru, 1-D model (modrá), tabulka dat (červená)

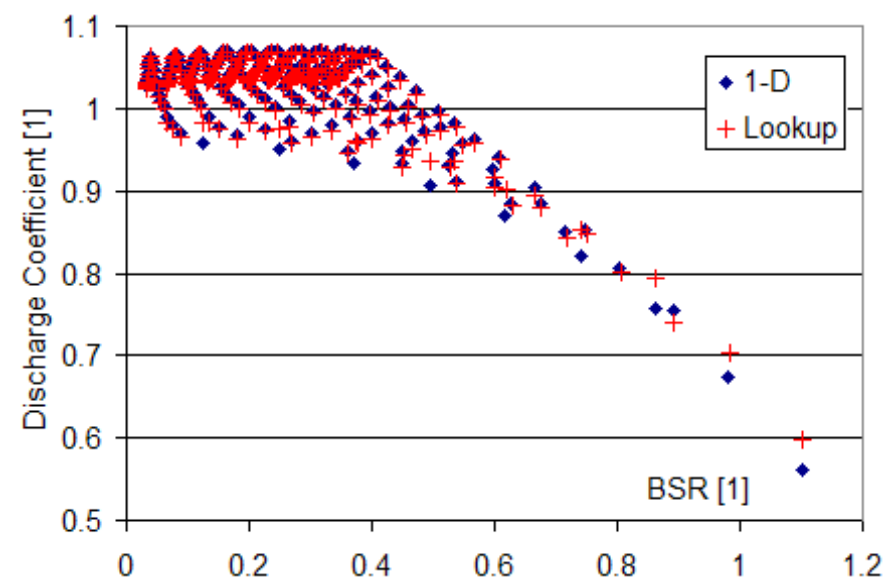

FIGURE 9: Dependence of discharge coefficient on blade speed ratio, 1-D model (blue), Lookup table (red)

OBRÁZEK 9: Závislost hltnostního součinitele na rychlostním poměru, 1-D model (modrá), tabulka dat (červená)

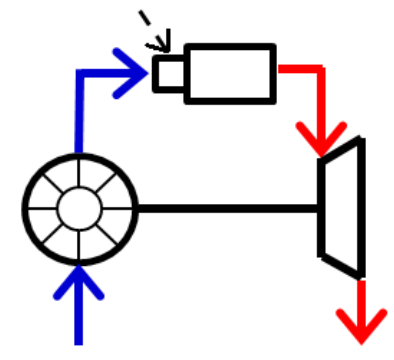

FIGURE 10: Schematic diagram of a virtual hot gas stand (compressor, burner, turbine)

OBRÁZEK 10: Schéma virtuálního zkušebního stavu se spalovací komorou (kompresor, komora, turbína)

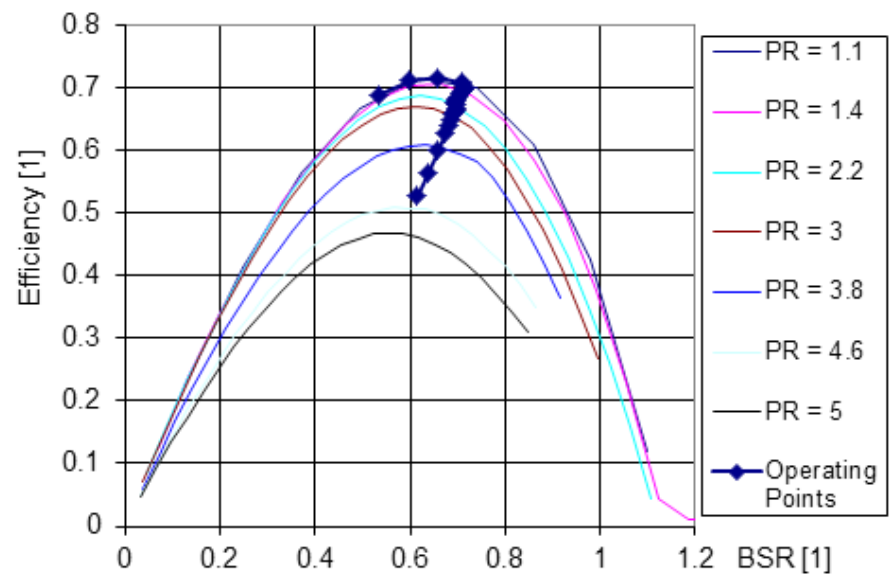

FIGURE 11: Dependence of efficiency on blade speed ratio, operating points of the 1-D turbine loaded with reference compressor wheel, lines with constant pressure ratio (PR)

OBRÁZEK 11: Závislost účinnosti na rychlostním poměru, pracovní body 1-D modelu turbíny zatěžované referenčním kompresorovým kolem, čáry s konstantním tlakovým poměrem

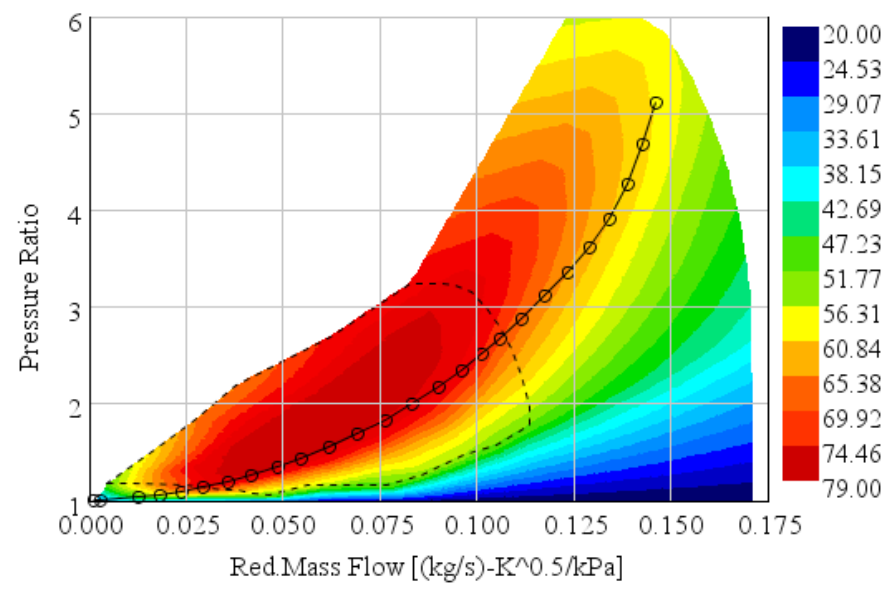

FIGURE 12: Compressor efficiency map with working points OBRÁZEK 12: Mapa kompresoru s pracovními body 
high pressure ratios, when transonic flow occurs, is complicated because there is a lack of experimental data for detailed modelling of in-turbine processes. This type of experiment is very expensive.

The compressor average working points (the black circles) are shown in Figure 12. There are two areas in the compressor map, the part based on input data and the extrapolated part. The aim was to test the turbine model over a wide area, so that compressor map extrapolation was unavoidable. The useful operating range of a compressor is limited by the surge line and the choke limit. The dependence of efficiency on blade speed ratio of various turbine models is depicted in Figure 13. There is a comparison between 1-D model, 0-D SAE map with user fitting, 0-D using the lookup table and the regression model based on experiments. The turbines have been loaded by the same compressor with a reference diameter. The initial (25 kRPM) and final (130 kRPM) turbocharger speeds were identical in all mentioned cases. The obtained simulation results are comparable.

The hot gas stand model is a useful tool for turbine-compressor matching [6]. The goal of the matching procedure is to find the appropriate compressor wheel for given turbine. The compressor must keep the turbine within its high efficiency region. The performance of the 1-D turbine (type CZ K36) loaded by various compressors corresponds to expectations, (Figure 14) and (Figure 15). The turbine is unloaded in conjunction with a small compressor and overloaded with a large one. The load of a turbine is also influenced by the inlet temperature. The presented compressors have been obtained by utilization of a speed lines multiplier. Both compressors (larger and smaller) utilize the speed lines of a reference compressor multiplied by a coefficient, which has been applied to the compressor speed. The coefficient is 0.75 in the case of the large compressor wheel and 1.25 in the case of the small one. This procedure is suitable as a first approximation at the beginning of turbine-compressor matching. A turbine must work with the highest possible efficiency.

\subsection{VIRTUAL HOT GAS STAND - TRANSIENT STATE}

As mentioned above, the developed model of a one-loop hot gas stand enables simulation of transient states. The turbocharger performance is controlled by the amount of fuel over time. The goal was to test the behaviour and to verify the robustness of the current 1-D turbine model in transient states. Two variants of transients (Transient A, Transient B) were simulated. The 1-D turbine (CZ K36) was loaded by the identical type of compressor (reference) for both steady state and transients. The initial turbocharger speed (30 kRPM) was the same for both transient states. Figure 16 shows the fuel mass flow rate during the tests. The results in Figure 17 and Figure 18 are compared with the

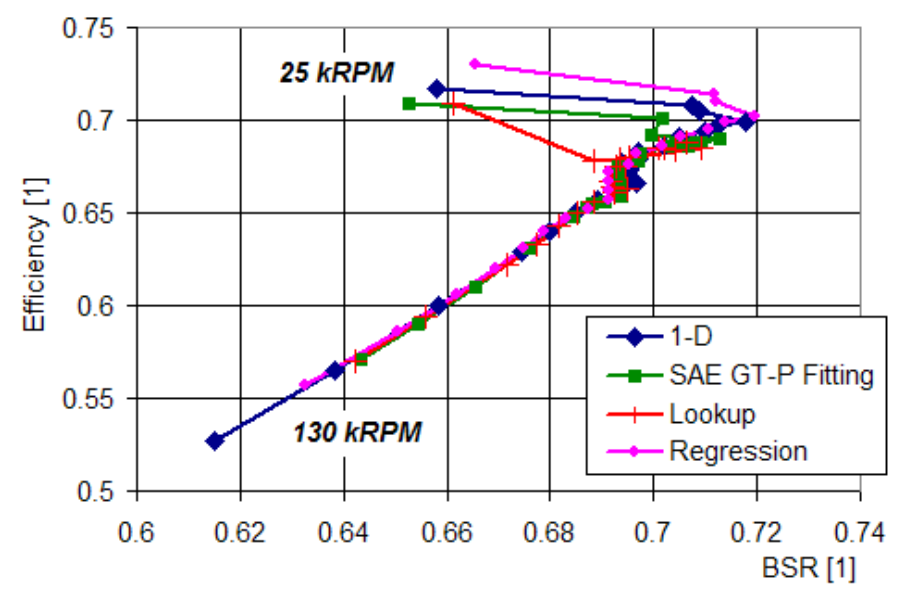

FIGURE 13: Dependence of efficiency on blade speed ratio, comparison of different turbine models (1-D, SAE with user fitting in GT-Power, Lookup table, Regression model based on experimental data)

OBRÁZEK 13: Závislost účinnosti na rychlostním poměru, porovnání různých modelů turbíny (1-D, SAE mapa s uživatelskou reprezentací dat v GT-

Power, tabulka dat, regresní model založený na experimentálních datech)

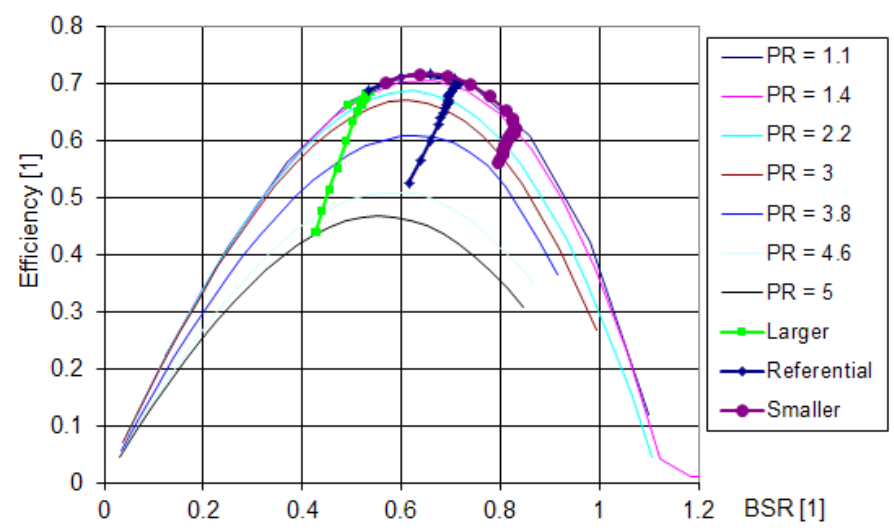

FIGURE 14: Dependence of efficiency on blade speed ratio, 1-D turbine loaded by compressors with different wheels (large, reference and small wheel diameter)

OBRÁZEK 14: Závislost účinnosti na rychlostním poměru, 1-D model turbíny zatěžované kompresory s rưznými koly (velký, referenční a malý průměr kola)

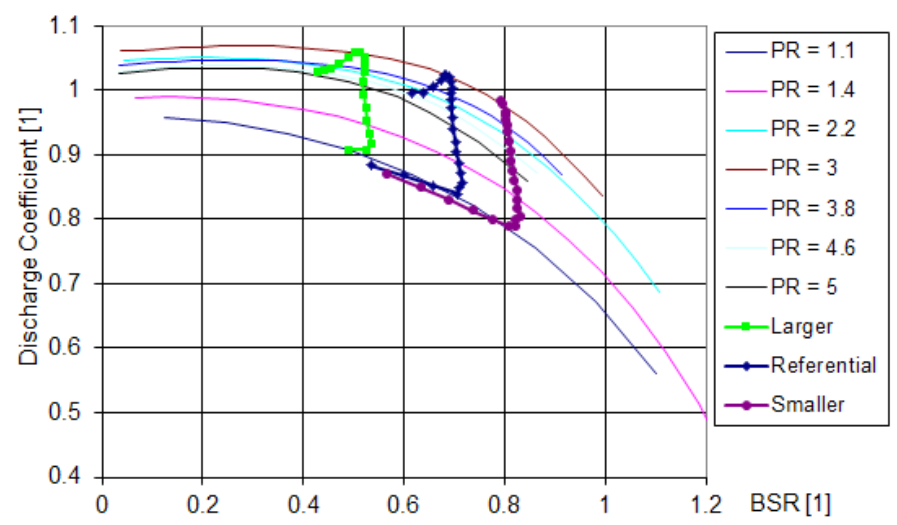

FIGURE 15: Dependence of discharge coefficient on blade speed ratio, 1-D turbine loaded by different compressors

OBRÁZEK 15: Závislost hltnostního součinitele na rychlostním poměru, 1-D model turbíny zatěžované různými kompresory 


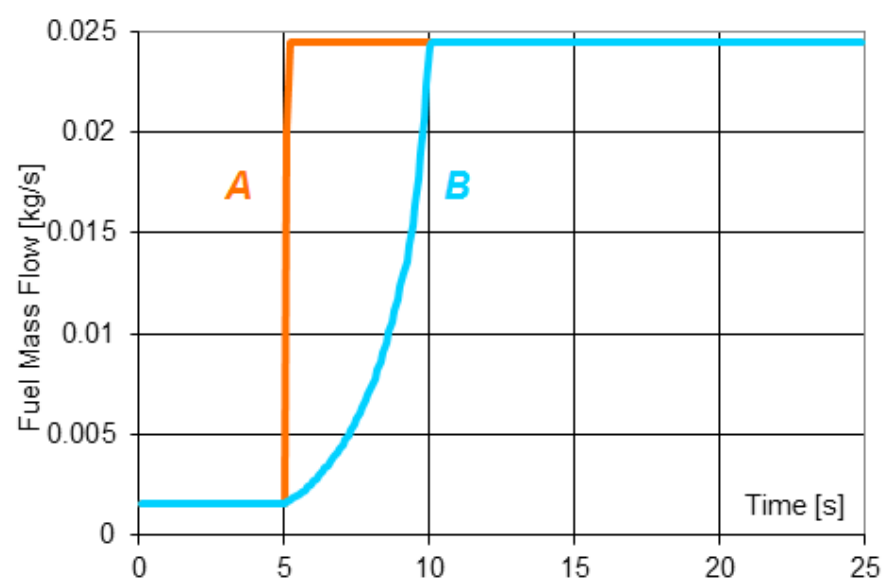

FIGURE 16: Fuel mass flow rate during transient state (Transient A, Transient B)

OBRÁZEK 16: Průtok paliva při přechodových režimech

(Transient A, Transient B)

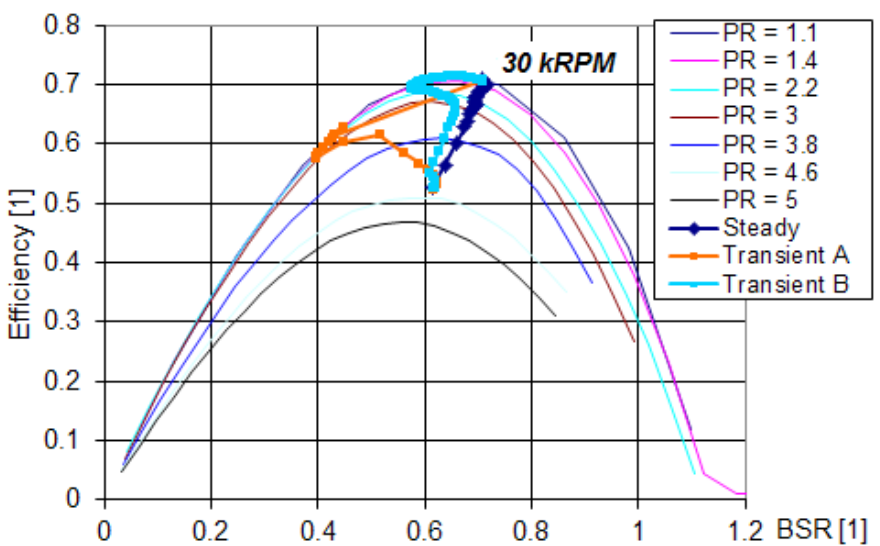

FIGURE 17: Graph of efficiency against blade speed ratio, comparison of 1-D turbine model behaviour during transient states and at steady states

OBRÁZEK 17: Průběh účinnosti v závislosti na rychlostním poměru, porovnání chování 1-D modelu turbíny v přechodových a stacionárních režimech

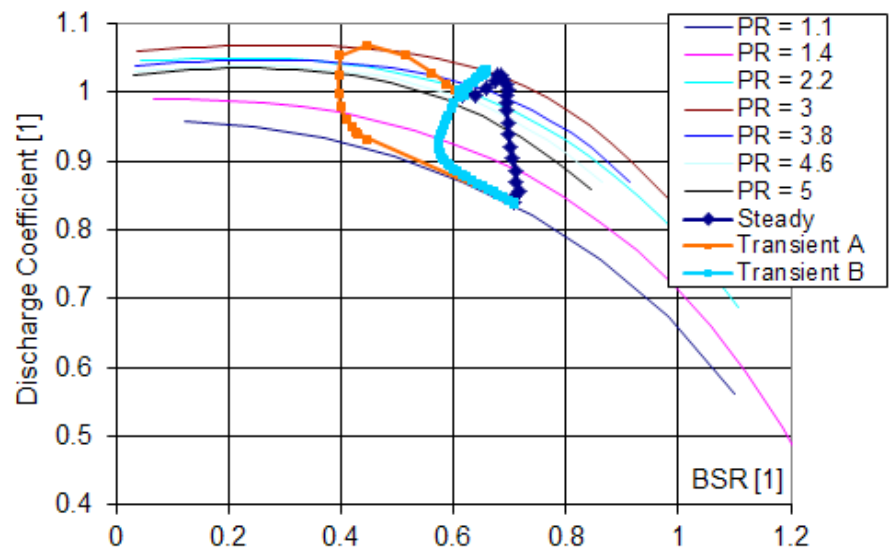

FIGURE 18: Graph of discharge coefficient against blade speed ratio, 1-D turbine model, transient and steady states

OBRÁZEK 18: Průběh hltnostního součinitele v závislosti na rychlostním poměru, 1-D model turbíny, přechodové a stacionární režimy steady state simulation. The immediate turbine overload at the beginning of Transient A corresponds to the step increase in fuel mass flow rate. A comparison of the behaviour of different turbine models during the Transient B is shown in Figure 19. The conditions were the same for all models. The transient started at turbocharger speed of $30 \mathrm{kRPM}$ and finished at a speed of 130 kRPM. The performance of displayed turbines is comparable.

\subsection{VIRTUAL SI ENGINE}

The next step was to simulate the turbine performance in conjunction with a reciprocating four-stroke spark ignition internal combustion engine. The basic parameters of the virtual engine model are shown in Table 1.

\begin{tabular}{|c|c|}
\hline Bore $[\mathrm{mm}]$ & 100 \\
\hline Stroke $[\mathrm{mm}]$ & 100 \\
\hline Displacement [dm3] & 3.14 \\
\hline Configuration & 4-cylinder in-line \\
\hline Ignition order & $1-3-4-2$ \\
\hline Turbine type & $\mathrm{CZ}$ C12 \\
\hline
\end{tabular}

The preliminary simulation results of the unsteady 1-D turbine model (single entry turbine, type CZ C12) in comparison with the 0-D model (SAE format with user fitting in GT-Power, map based on the results of the 1-D model on the virtual test bed) are displayed in following diagrams. The air excess was constant and identical in both cases. The pressure ratio plots during the engine cycle in Figure 20 are comparable. The patterns of mass flow rate through the turbine in Figure 21 are similar. The unsteady efficiency plot (Figure 22) reflects the energy and mass accumulation in the 1-D model. The average efficiency of 1-D is slightly higher in comparison with the $0-D$. The instantaneous power patterns are shown in Figure 23. The average turbine power is slightly higher in the case of the 1-D model. The plots of blade speed ratio over the engine cycle are given in Figure 24 .

\section{CONCLUSION}

The goal of the work was to verify the potential of the current 1-D turbine model. The unsteady physical model has proved its robustness, reliability and predictive capability at steady and transient states on a one-loop hot gas stand. The virtual turbine test bed, as a strong simulation tool in the process of evaluation and verification of various turbine models over a wide working range, enables generation of 0-D turbine maps based on the 1-D results with an acceptable level of accuracy. The advantage of the 1-D unsteady model is its physically based extrapolation. 


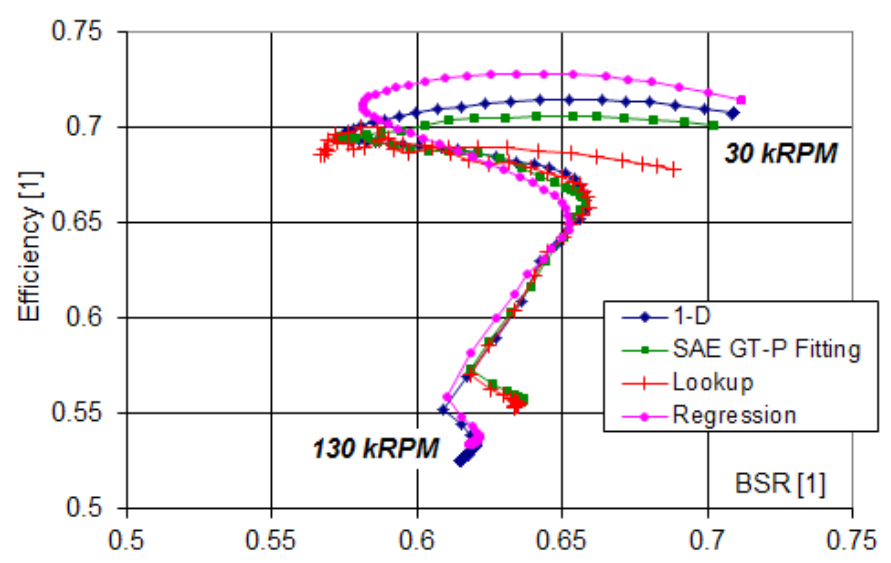

FIGURE 19: Graph of efficiency against blade speed ratio during Transient $B$, comparison of different turbine models (1-D, SAE with user fitting in GT-Power, Lookup table, Regression model based on experimental data) OBRÁZEK 19: Průběh účinnosti v závislosti na rychlostním poměru při přechodovém režimu Transient $\mathrm{B}$, porovnání různých modelů turbíny (1-D, SAE mapa s uživatelskou reprezentací dat v GT-Power, tabulka dat, regresní model založený na experimentálních datech)

This feature is also very useful when the standard 0-D turbine maps are generated. The model's disadvantage is the relatively demanding calibration based on turbocharger measurement. Further simulations in conjunction with the different types of reciprocating internal combustion engines at steady and transient states are in-process. The twin scroll turbine 1-D model development will follow in the future. The results of the complex optimization of the 1-D combustion engine model with 1-D turbine offer new capabilities in turbine-compressor matching and the turbocharger development process.

\section{ACKNOWLEDGEMENT}

The work has been supported by the Centralized Development Project CSM 100 - TALENT of Ministry of Education, Youth and Sports, Czech Republic (MŠMT CSM 100 - TALENT).

This research has been realized using the support of EU Regional Development Fund in OP R\&D for Innovations (OP VaVpl) and Ministry for Education, Czech Republic, project \# CZ.1.05/2.1.00/03.0125 Acquisition of Technology for Vehicle Center of Sustainable Mobility and the support of Technological Agency, Czech Republic, programme Centres of Competence, project \# TE01020020 Josef Božek Competence Centre for Automotive Industry.

All the support is gratefully acknowledged.

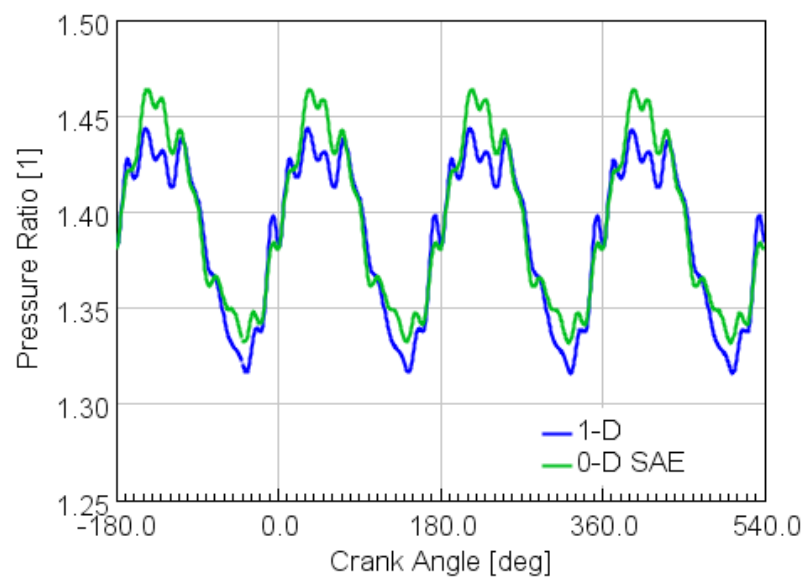

FIGURE 20: Turbine pressure ratio over the engine cycle, $\mathrm{BMEP}=10.8 \mathrm{bar}$, 1800 RPM, comparison of 1-D turbine model and 0-D SAE with user fitting in GT-Power

OBRÁZEK 20: Tlakový poměr na turbíně v průběhu cyklu motoru, BMEP=10.8 bar, 1800 RPM, porovnání 1-D modelu turbíny a 0-D SAE mapy s uživatelskou reprezentací dat v GT-Power

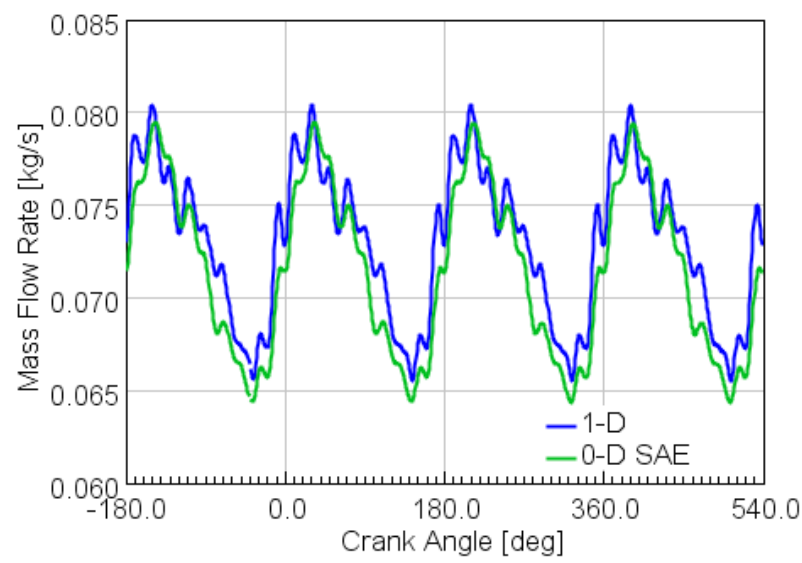

FIGURE 21: Mass flow rate via the turbine over the engine cycle, $\mathrm{BMEP}=10.8 \mathrm{bar}$, $1800 \mathrm{RPM}$, comparison of 1-D turbine model and 0-D SAE with user fitting in GT-Power OBRÁZEK 21: Hmotnostní průtok turbínou v průběhu cyklu motoru, BMEP=10.8 bar, 1800 RPM, porovnání 1-D modelu turbíny a 0-D SAE mapy s uživatelskou reprezentací dat v GT-Power

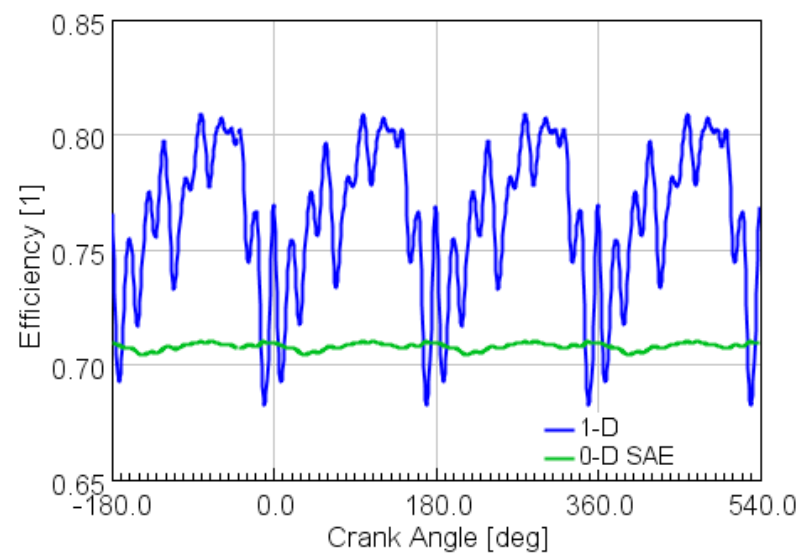

FIGURE 22: Turbine efficiency over the engine cycle, BMEP=10.8 bar, 1800 RPM, comparison of 1-D turbine model and 0-D SAE with user fitting in GT-Power OBRÁZEK 22: Účinnost turbíny v průběhu cyklu motoru, BMEP=10.8 bar, 1800 RPM, porovnání 1-D modelu turbíny a 0-D SAE mapy s uživatelskou reprezentací dat v GT-Power 


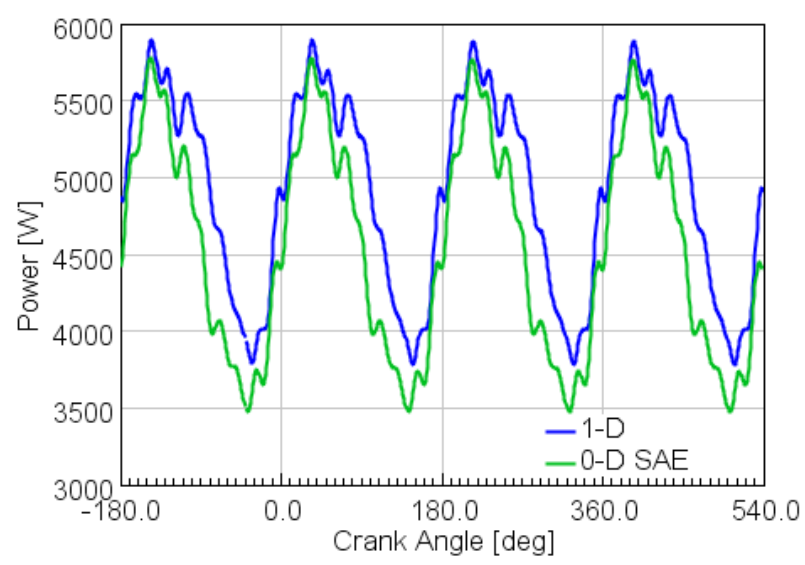

FIGURE 23: Turbine power over the engine cycle, BMEP=10.8 bar, 1800 RPM, comparison of 1-D turbine model and 0-D SAE with user fitting in GT-Power

OBRÁZEK 23: Výkon turbíny v průběhu cyklu motoru, BMEP=10.8 bar, 1800 RPM, porovnání 1-D modelu turbíny a 0-D SAE mapy s uživatelskou reprezentací dat v GT-Power

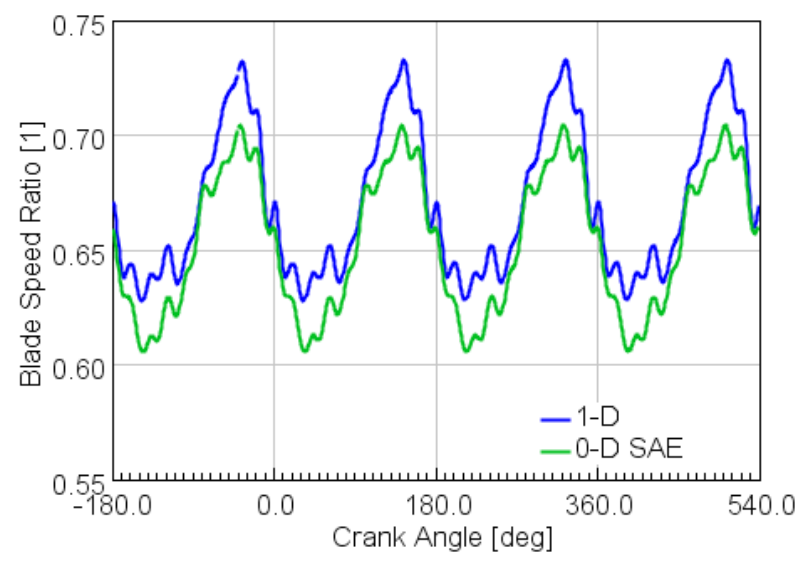

FIGURE 24: Turbine blade speed ratio over the engine cycle, $B M E P=10.8$ bar, 1800 RPM, comparison of 1-D turbine model and 0-D SAE with user fitting in GT-Power OBRÁZEK 24: Rychlostní poměr turbíny v průběhu cyklu motoru, $B M E P=10.8$ bar, 1800 RPM, porovnání 1-D modelu turbíny a 0-D SAE mapy s uživatelskou reprezentací dat v GT-Power

\section{REFERENCES}

[1] ZINNER K. (1978). Supercharging of Internal Combustion Engines. Springer Heidelberg.

[2] DIXON S. L. (1975). Fluid Mechanics, Thermodynamics of Turbomachinery. Pergamon Press London

[3] GT-POWER User's manual and Tutorial GT-Suite version 7.0, Gamma Technologies Inc., 2009.

[4] HEYWOOD, J. B. (1988). Internal Combustion Engine Fundamentals. McGraw-Hill series in mechanical engineering, printed in USA. McGraw-Hill. ISBN 0-07-028637-X.

[5] MACEK, J. , KLIMENT, V. Gas Turbines, Turbochargers and Fans. CTU in Prague, 1992-1996. ISBN 80-01-00840-1. (In Czech).

[6] VÍTEK O., MACEK J., POLÁŠEK M. (2006). New Approach to Turbocharger Optimization using 1-D Simulation Tools. SAE Paper 2006-01-0438.

[7] MACEK J., VÁVRA, J. - VÍTEK, O. (2002). 1-D Model of Radial Turbocharger Calibrated by Experiments. SAE Paper 200201-0377. In: Modeling of SI Engines and Multi-Dimensional Engine Modeling. Warrendale, PA: Society of Automotive Engineers, Vol. 1, p. 173-194. ISBN 0-7680-0970-7

[8] MACEK J., VÍTEK 0. (2008). Simulation of Pulsating Flow Unsteady Operation of a Turbocharger Radial Turbine. SAE Paper 2008-01-0295

[9] MACEK, J., VÍTEK, O., ŽÁK, Z. (2011). Calibration and Results of a Radial Turbine 1-D Model with Distributed Parameters. SAE Technical Paper 2011-01-1146.

[10] MACEK J., VÍTEK O., BURIČ J., DOLEČEK V. (2009). Comparison of Lumped and Unsteady 1-D Models for Simulation of a Radial Turbine. SAE Paper 2009-01-0303

[11] VÁVRA J., MACEK J., VÍTEK O., TAKÁTS M. (2009). Investigation of Radial Turbocharger Turbine Characteristics under Real Conditions. SAE Paper 2009-01-0311 